SEX WORK

\title{
What happens to women who sell sex? Report of a unique occupational cohort
}

H Ward, S Day

See end of article for authors' affiliations .....................

Correspondence to: Helen Ward, Department of Infectious Disease Epidemiology, Imperial College London, Norfolk Place, London W2 1PG, UK; h.ward@imperial.ac. uk

Accepted for publication 5 June 2006

Published Online First

21 June 2006
Background/objectives: Sex work has been seen as both a health and a social problem. However, there is a paucity of evidence on the longer term impact on health. We explored the health and career paths over a period of 15 years among women who have worked in the sex industry.

Design: A longitudinal study of sex workers recruited between 1986 and 1993 and followed for 15 years. Outcome data were obtained through interview, clinic records, or third parties.

Setting: Clinic and community settings in London.

Participants: We obtained outcome data on 130 (37\%) of the original cohort of 354 women, with a combined follow up of 1247 years.

Main outcome measures: Vital status, most recent occupation, duration of sex work, sexually transmitted infections (STI), major health problems.

Results: The majority $(73 / 124,59 \%)$ were still in the sex industry and had sold sex for a mean of 13.6 years. There were six deaths, a mortality of 4.8 per 1000 person years. Surviving women had a high cumulative risk $(110$ of $118,93 \%)$ of STI. Past gonorrhoea was associated with pelvic inflammatory disease (RR 2.28, 95\% Cl 1.12 to 4.66) and infertility (RR 10.9, 95\% Cl 1.5 to 77.3). Other outcomes included mental health problems (38 of $97,40 \%$ ) and addiction (46 of 72,64\%). There were no significant differences in health outcomes between women who were still in the sex industry and those who had stopped. There was a high level of occupational mobility, and 31 women (of 84, 37\%) had completed vocational or higher education, including eight to postgraduate level.

Conclusions: Sex work is associated with excess mortality and morbidity including the sequelae of STI, mental health problems, and substance misuse. The relation between these health problems and sex work is complex.
$\mathrm{S}$ ex work has been seen as a problem: a threat to public health, public order, decency, the formal economy, the integrity of borders, and women's rights. ${ }^{1}$ Responses range from repression, especially of sex workers, to liberalisation and decriminalisation. Most policy debates share the premise that the sex industry is harmful to participants; its workers are considered to be socially excluded and vulnerable. This belief underpins recent policy changes in the United Kingdom. ${ }^{23}$ One key part of government proposals is to emphasise "exiting" strategies-mechanisms for helping people leave the industry and become reintegrated into society.

Unfortunately there is little evidence to support such policies. While the short term impact of sex work on health has been studied extensively in recent decades, ${ }^{4-6}$ prompted by concerns about the risks of HIV, little is known about the longer term impact. In common with others, we have conducted short term studies and found that sex workers in the United Kingdom face increased risks of HIV and other sexually transmitted diseases and blood borne viruses. ${ }^{7}$ In addition to infection risks, some studies have identified psychological morbidity as a common outcome in the short term. ${ }^{8}$ Few long term studies have been conducted since sex work is widely considered a transient occupation and long term follow up problematic. We have previously reported findings from the first period of a cohort study with a follow up for a median of 18 months. ${ }^{7}$ We identified an increased mortality rate, a finding echoed in work from the United States. ${ }^{9}$ In this paper, we report from this unique cohort study on the longer term impact of sex work on women's health and careers, exploring the career path of women both within and outside the sex industry.

\section{METHODS}

We established a cohort of sex workers in London between 1986 and 1993. Detailed methods, baseline findings, and initial follow up data have been reported elsewhere. ${ }^{7} 1011$ Briefly, from 1985 to the end of 1991, women working in the sex industry were enrolled in a cohort study based in an inner London genitourinary medicine department, where a special clinical and outreach service, the Praed Street Project, was developed for sex workers. ${ }^{12}{ }^{13}$ Women were eligible for the study if they defined themselves as sex workers and had worked within the past 3 months. While it was not possible to establish whether the study was strictly representative of the local sex industry, methods of recruitment were as inclusive as possible including women attending the clinic, their colleagues and friends, plus direct recruitment through outreach to local streets, escort agencies, flats, and saunas. Women were interviewed using a semi-structured schedule and offered screening for sexually transmitted infections with informed consent. For the purposes of this paper we refer to an initial cohort of 354 women recruited between 1986 and 1993 who were interviewed at least twice and consented to ongoing research.

From 1997 to 2000 we attempted to re-contact these women. Those who were still attending the sexual health clinic or local sex worker service were approached directly. Others were contacted at their last known address or phone number. When these attempts failed, we established simple outcome measures through a review of case notes or information volunteered by other participants. Mortality data

Abbreviations: CIN, cervical intraepithelial neoplasia; STI, sexually transmitted infections 


\begin{tabular}{|c|c|c|c|c|}
\hline & & \multicolumn{2}{|c|}{ Followed up after 1993} & \multirow[b]{3}{*}{ p Value } \\
\hline & & \multirow{2}{*}{$\begin{array}{l}\text { Yes }(n=130) \\
\text { No }(\%)\end{array}$} & \multirow{2}{*}{$\begin{array}{l}\text { No }(n=255) \\
\text { No }(\%)\end{array}$} & \\
\hline & & & & \\
\hline Age & $\begin{array}{l}\text { Range } \\
\text { Median (IQR) }\end{array}$ & $\begin{array}{l}16-51 \\
27(23,31)\end{array}$ & $\begin{array}{l}17-52 \\
24(22,29)\end{array}$ & 0.01 \\
\hline Country of birth & UK & $95 / 124$ (77) & $144 / 205(70)$ & 0.21 \\
\hline Ethnicity & White (British) & $78 / 119$ (73) & $127 / 166(76)$ & \\
\hline \multirow{2}{*}{$\begin{array}{l}\text { Age left full time education } \\
\text { (years) }\end{array}$} & $<16$ & $30(31)$ & $43(26)$ & 0.55 \\
\hline & $\begin{array}{l}16-18 \\
>18 \\
\text { Missing }\end{array}$ & $\begin{array}{l}55(57) \\
12(12) \\
33\end{array}$ & $\begin{array}{l}106(64) \\
18(11) \\
167\end{array}$ & \\
\hline \multirow{3}{*}{$\begin{array}{l}\text { Injection drug use } \\
\text { Months in sex work }\end{array}$} & Ever & $13 / 117(11)$ & $15 / 219(7)$ & 0.19 \\
\hline & Range & $1-216$ & $1-324$ & \\
\hline & Median (IQR) & $36(15,72)$ & $21(8,52)$ & 0.003 \\
\hline \multirow[t]{6}{*}{ Sex work sector } & Street & $25(21)$ & 31 (15) & 0.04 \\
\hline & Escort & $55(45)$ & $113(45)$ & 0.97 \\
\hline & Sauna & $16(31)$ & 28 (11) & 0.81 \\
\hline & & $24(20)$ & $46(18)$ & 0.91 \\
\hline & Other & $2(2)$ & $1(1)$ & 0.26 \\
\hline & Missing & 8 & 6 & \\
\hline
\end{tabular}

are based on reports from other sex workers or family members. We did not consult official mortality reports, as we had not obtained specific consent for this record linkage. We recorded outcome data from 1997 onwards.

Outcome data were collected using a structured questionnaire, or through completion of a data collection form from third party information. Women provided informed consent.

We analysed occupational mobility within and outside the sex industry. We used four categories for analysis based on the local industry: street, escort (which includes working for a madam and privately), sauna (sex work businesses including clubs), and flat (sex work businesses where women tend to work on their own). We focus on the sale of sex, but look also at other sex work jobs such as being a maid, agent and working for one client or "sugar daddy." We categorised non-sex work jobs broadly into manual, semi-skilled, skilled, and professional.

Health outcomes were collected through the use of precoded interview questions, including specific questions on sexually transmitted infections (STI), self defined addiction and mental health problems, as well as open questions. Health issues were validated where possible by clinical records, and participants were invited to another sexual health check. Alcohol misuse was defined for interviewees using the CAGE scoring system. ${ }^{14}$

Questionnaire data were coded and stored electronically and analysis was carried out using SPSS. The different methods of collecting the data have led to missing values in a number of variables as indicated by the varying denominators. Comparisons were carried out using $\chi^{2}$ tests for categorical variables and presented as odds ratios (OR) with 95\% confidence intervals (CI). Bias because of loss to follow up was explored by comparing baseline characteristics of those who were followed up with those who were lost. Categorical variables were compared using $\chi^{2}$ tests, continuous variables were either grouped and similarly tested, or tested using non-parametric methods. Significance was set at the $5 \%$ level using two tailed tests.

This study had institutional ethics committee approval.

\section{RESULTS}

We obtained outcome data on 130 of the 354 women, a follow up rate of $37 \%$. Sixty women were contacted directly,
Table 2 Outcome: lifetime risk of sexually transmitted infections (STI)*

\begin{tabular}{|c|c|}
\hline Ever had infection & $\begin{array}{l}\text { No }(\%) \\
(n=118) \dagger\end{array}$ \\
\hline $\begin{array}{l}\text { Gonorrhoea } \\
\text { Chlamydia } \\
\text { Syphilis } \\
\text { Trichomoniasis } \\
\text { Genital herpes (clinical) } \\
\text { Genital warts } \\
\text { Pelvic inflammatory disease } \\
\text { Any STI }\end{array}$ & $\begin{array}{l}67(57) \\
75(64) \\
9(8) \\
58(49) \\
47(40) \\
37(31) \\
33(28) \\
110(93)\end{array}$ \\
\hline \multicolumn{2}{|c|}{$\begin{array}{l}\text { *Lifetime risk is obtained by combining reports of past STI } \\
\text { from interviews (at baseline and follow up) with records of } \\
\text { STI documented in clinic notes. } \\
\text { †Excludes six women with no reliable outcome measure of } \\
\text { STI. } \\
\text { †Any STI includes all of the other reported infections but } \\
\text { excludes other genital conditions such as candidiasis. }\end{array}$} \\
\hline
\end{tabular}

47 of whom were interviewed, and 13 took part in more informal discussions. For 28 of the remaining 70, information was obtained from a third party (another sex worker or relative), and for 42 it was obtained from clinic or project records. The combined follow up time for these women was 1247 years (mean 9.6 years, range 6-15).

\section{Loss to follow up bias}

Women who were followed up are a distinct subset of the initial cohort as shown in table 1 . Those followed up varied in baseline characteristics and had been significantly older, had been working in the sex industry for longer, and were more likely to work privately or on the streets than those who were lost. There were no significant differences in other demographic characteristics, family, or health status.

\section{What happened to the women?}

Six of the 130 women had died: four deaths have been reported in an earlier paper, ${ }^{7}$ including two with AIDS and two who were murdered. Another woman died of alcoholic liver disease in her mid-30s, and the last reportedly from a drug overdose in her early 40s. Given a total of 1247 years of follow up, this mortality is 4.8 per 1000 person years. 


\begin{tabular}{|c|c|c|c|}
\hline \multirow[b]{3}{*}{ Health problem } & \multicolumn{2}{|c|}{ Current sex worker } & \multirow{3}{*}{$\begin{array}{l}\text { Odds ratio } \\
(95 \% \mathrm{Cl})\end{array}$} \\
\hline & \multirow{2}{*}{$\begin{array}{l}\begin{array}{l}\text { Yes }(n=45) \\
\text { unless specified }\end{array} \\
\text { No }(\%)\end{array}$} & \multirow{2}{*}{$\begin{array}{l}\text { No }(n=47) \\
\text { unless specified } \\
\text { No }(\%)\end{array}$} & \\
\hline & & & \\
\hline Mental health problem & $18(40)$ & $20(43)$ & $0.87(0.40$ to 1.99$)$ \\
\hline Reproductive health problem & $15(33)$ & $18(38)$ & $0.81(0.34$ to 1.89$)$ \\
\hline Sub-fertility & $10(22)$ & $10(21)$ & 0.91 (0.34 to 2.48$)$ \\
\hline Musculoskeletal problems & $7(16)$ & & $2.70(0.65$ to 11.18$)$ \\
\hline Hepatitis C & $4 / 29(14)$ & $4 / 32(13)$ & $1.12(0.25$ to 4.96$)$ \\
\hline Problem alcohol use & $12 / 21(57)$ & $3 / 12(25)$ & $4.00(0.83$ to 19.16$)$ \\
\hline Smoker & $30 / 44(68)$ & $21 / 27(78)$ & $0.61(0.20$ to 1.85$)$ \\
\hline
\end{tabular}

The remaining 124 women were aged from 24 years to 62 years at follow up, (median 36.5 years); most (90/110, $82 \%$ ) were living in London, five overseas, and the rest spread across the United Kingdom. Just over half (65/124, 52\%) had a regular partner (husband, boyfriend, or girlfriend). For 56 women providing household details, 38 (68\%) were living alone, almost half $(24 / 50,48 \%)$ owned their own homes. The majority (102/1 14, 89\%) had been pregnant but less than half (46/113, 41\%) had given birth to children, the proportion rising with age: of 15 women aged over 45 , nine (60\%) had children.

\section{Health}

In addition to the high mortality, there were significant health problems including a high cumulative risk of STI, mental health problems, and addiction. A total of 110 (93\%) had one or more STI (see table 2) These infections were associated with longer term sequelae: those with gonorrhoea had a doubling of risk of pelvic inflammatory disease (OR 2.3, 95\% CI 1.1 to $4.7, p=0.02$ ), and an 11 -fold increase in the risk of requiring investigation for infertility (OR 10.9, 95\% CI 1.5 to $77.3, p=0.001)$. Almost half had at least one abnormal cervical cytology report ( 45 of $94,48 \%$ ), including seven (7\%) who had cervical intraepithelial neoplasia (CIN). Five women cited recurrent genital herpes as a significant health problem at follow up. Eight women (of 63 tested, 13\%) had hepatitis C; eight (of 98, 8\%) had previous hepatitis B. None of the surviving women had HIV infection (98 were tested at follow up).

A range of other chronic health problems were reported by 97 women, including gynaecological (36 women), musculoskeletal (10), and cardiovascular (6). The most common chronic or incapacitating problems related to mental health: 38 women (40\%) reported significant mental health problems including depression, psychosis, and eating disorders, and 46 (of 72, 64\%) reported previous or current addiction. Addiction was one indication of relatively high rates of substance use: 18/94 (19\%) had injected drugs at some point in their lives; 50 of $72(72 \%)$ currently smoked cigarettes and a further 41 took non-prescription drugs. Alcohol consumption appeared to be high, although we only obtained detailed reports from 33 women completing an extended interview; 18 scored one or more on the CAGE scale for problem alcohol use, 15 of whom described themselves as having an alcohol problem. We found no major difference in health outcomes between those who left and those who remained in the sex industry (table 3).

\section{Occupational mobility}

Most women had left school without going on to further education: $30 / 91$ (33\%) left before the age of 16, $45(49 \%)$ between 16 and 18 , and $16(18 \%)$ over the age of 18 . On leaving school, 28/92 (30\%) went straight into sex work; this proportion was higher among women who left school before they were $16(10 / 22,45 \%)$ but the difference was not statistically significant. A further 10 worked in entertainment, including stripping, bar work, and singing; 25 had semi-skilled jobs such as hairdressing, secretarial, and shop work; five had professional jobs requiring qualifications such as nursing; nine had manual jobs such as factory work; 13 were mothers or wives with no other jobs initially; and two went into vocational training.

Seventy seven women described the circumstances in which they started selling sex. The majority $(42,55 \%)$ were introduced by another female, usually a friend who was already working. A further $16(21 \%)$ entered the work without any introduction, usually through contacting an escort agency or sauna directly; 12 were introduced by a man, and five reported being coerced or solicited. Looking specifically at 28 women who first worked on the streets,

Table 4 Mobility of women between sectors of the sex industry by first work sector

\begin{tabular}{|c|c|c|c|c|c|c|c|}
\hline \multirow[b]{3}{*}{ First sector* } & \multirow[b]{3}{*}{ No } & \multicolumn{4}{|c|}{ Worked in sector at any time } & \multicolumn{2}{|l|}{ Worked in } \\
\hline & & \multirow{2}{*}{$\begin{array}{l}\text { Street } \\
\text { No (row \%) }\end{array}$} & \multirow{2}{*}{$\begin{array}{l}\text { Escort } \\
\text { No (row \%) }\end{array}$} & \multirow{2}{*}{$\begin{array}{l}\text { Sauna } \\
\text { No (row \%) }\end{array}$} & \multirow{2}{*}{$\begin{array}{l}\text { Flat } \\
\text { No (row \%) }\end{array}$} & \multirow{2}{*}{$\begin{array}{l}\text { All sectors } \\
\text { No (row \%) }\end{array}$} & \multirow{2}{*}{$\begin{array}{l}\text { One sector onl) } \\
\text { No (row \%) }\end{array}$} \\
\hline & & & & & & & \\
\hline Street & 35 & - & $27(77)$ & $21(60)$ & $30(86)$ & $16(46)$ & $1(3)$ \\
\hline Escort & 31 & $9(29)$ & - & $13(42)$ & 11 (35) & $6(19)$ & $14(45)$ \\
\hline Sauna & 22 & $12(55)$ & $18(82)$ & - & $12(55)$ & $8(36)$ & $3(14)$ \\
\hline Flat & 16 & $4(25)$ & $11(69)$ & $9(56)$ & - & $4(25)$ & $5(31)$ \\
\hline Not known & 14 & $6(43)$ & $13(93)$ & $9(64)$ & $9(64)$ & 0 & nkf \\
\hline All† & 118 & $66(56)$ & $100(85)$ & $74(63)$ & $78(66)$ & $34(29)$ & $23(19)$ \\
\hline
\end{tabular}

*"Street" refers to direct soliciting on the street or around a hotel; "escort" includes escort agencies, working via a madam, or working through private referrals from colleagues or clients; "sauna" includes working in a massage parlour, sauna or sex club; "flat" includes working in a privately rented flat or a brothel. tExcludes women with incomplete data on sector over time. fUnable to assess because of lack of information on first sector. 
Table 5 Occupational mobility from leaving full time education to time of most recent follow up

\begin{tabular}{|c|c|c|c|c|c|c|c|}
\hline \multirow[b]{3}{*}{ First occupation ${ }^{*}$} & \multirow[b]{3}{*}{ No } & \multicolumn{6}{|c|}{ Occupation at most recent follow up } \\
\hline & & \multirow{2}{*}{$\begin{array}{l}\text { Sex industry† } \\
\text { No (row \%) }\end{array}$} & \multirow{2}{*}{$\begin{array}{l}\text { Skilled/semi-skilled } \\
\text { work } \\
\text { No (row \%) }\end{array}$} & \multirow{2}{*}{$\begin{array}{l}\begin{array}{l}\text { Manual/ } \\
\text { catering }\end{array} \\
\text { No (row \%) }\end{array}$} & \multirow{2}{*}{$\begin{array}{l}\text { Full time mother/ } \\
\text { home }\end{array}$} & \multirow{2}{*}{$\begin{array}{l}\begin{array}{l}\text { Professional/ } \\
\text { own business }\end{array} \\
\text { No (row \%) }\end{array}$} & \multirow{2}{*}{$\begin{array}{l}\text { Sickness benefit } \\
\text { No (row \%) }\end{array}$} \\
\hline & & & & & & & \\
\hline Sex industry & 25 & $14(56)$ & $3(12)$ & 0 & $3(12)$ & $4(16)$ & $1(4)$ \\
\hline $\begin{array}{l}\text { Skilled/semi-skilled } \\
\text { work }\end{array}$ & 24 & $18(75)$ & $2(8)$ & 0 & $1(4)$ & $1(4)$ & $2(8)$ \\
\hline Manual/catering & 17 & $10(59)$ & $3(18)$ & 0 & $1(6)$ & $3(18)$ & 0 \\
\hline $\begin{array}{l}\text { Full time mother/ } \\
\text { home }\end{array}$ & 13 & 10 (77) & 0 & 0) & $1(8)$ & $2(15)$ & 0 \\
\hline Professional & 3 & $1(33)$ & 0 & $1(33)$ & 0 & $1(33)$ & 0 \\
\hline All & 82 & $53(65)$ & $8(10)$ & $1(1)$ & $6(7)$ & $11(13)$ & $3(4)$ \\
\hline
\end{tabular}

*First occupation on leaving full time education. tIncludes selling sex as well as other sex industry roles, including working as a maid or managing an agency. Some women combined this with other work (see text for details).

16 were introduced by women, five by men, two were coerced, two were solicited, and three entered without introduction.

Table 4 shows the distribution of these women within sex work over time. A minority, 23/118 (19\%), remained in one "sector" and almost a third (34,29\%) worked in all sectors. The highest mobility was in women who first worked on the streets.

At the time of last recorded outcome many $(73 / 124,59 \%)$ were still in the sex industry. This was more likely for women who were contacted directly than those whose outcome was from records or third party $(47 / 60,78 \%$ compared with 26/64, $41 \%$, OR $2.05,95 \%$ CI 0.99 to 4.25 ). Fifty seven were selling sex, and they had done so for between 4.5 years and 35 years (mean 13.6 (SD 5.6) years). This time refers to the total time, excluding periods when they had stopped for more than 6 months. Ten were working as maids or managers and six were supported by a "sugar daddy." Forty six had not sold sex for at least 6 months; these women had previously sold sexual services for between 2 years and 21 years (mean 10 (SD 4.7) years, ).

Table 5 shows the final occupation for 82 of these women compared with their first job. The most common pattern was to leave school and go into a semi-skilled job, such as hairdressing or shop work, and finally to enter and remain in the sex industry. The second most common was to go straight into the sex industry and remain there. Women often combined jobs. We have further details for 51 women still working in the sex industry: 21 combined sex work with other jobs, five with education, 25 were only in the sex industry. Of the women who were no longer working in the sex industry, we only have detailed information for 12 women, 11 of whom had other jobs.

Thirty seven per cent of women (31/84) undertook further, higher, or vocational education during follow up. We have detailed information on nine women who undertook undergraduate education, two of whom subsequently left sex work, a further eight who studied at postgraduate level, four of whom left sex work. Seven of the nine women completing vocational training left sex work.

\section{DISCUSSION}

Sex work is associated with excess mortality and morbidity. The mortality documented in this paper is lower than previously found, but is still higher than expected for women in this age group. ${ }^{7}$ Some health problems, such as acute bacterial STI, may appear relatively minor but we have shown these to be associated with later problems such as infertility. Viral infections, associated with sexual exposure or drug use, can also lead to chronic problems ranging from problematic genital herpes to liver failure. The most significant problems related to mental ill health and substance misuse. The relation between these health problems and sex work is complex, and despite the longitudinal nature of this study, we are not able to determine causation. Multiple factors predispose sex workers in general to chronic ill health, including poverty and poor education. We were unable to control for these because of the relatively small numbers followed up, and limited baseline information on chronic health problems. However, it is clear that prejudice towards the sale of sex and legal penalties marginalised sex workers both during and after their time in the industry, and the majority of respondents attributed their symptoms to this burden of disrespect and the difficulties they faced in hiding what they did.

Despite the health problems, many women worked for a long time in the sex industry and remained when other choices presented themselves, such as those associated with completing vocational training or higher education. Therefore, these negative factors have to be assessed against the positive benefits to women's health and wellbeing. These data challenge assumptions about social status in sex work, including distinctions between work outdoors and indoors, in which street workers must be helped to find "proper" jobs while indoor workers might be tolerated and regulated by the state. $^{2}$

This study is limited by sampling and follow up bias. The women followed up are not representative of sex workers in general or even the baseline cohort. Because of the way we made contact with women through sex work projects and related networks, we were likely to over-represent those who had continued to work in the industry, those living in London, and those with ongoing health problems. In addition, data were missing on some variables. None the less, this study constitutes the only long term prospective study of its kind and challenges prevalent assumptions that sex work is necessarily a transient occupation, which is highly stratified, and intensifies social exclusion.

We have shown that in this cohort, many women worked for a long time in the sex industry and were highly mobile within it. Sex work is conventionally considered a highly segmented industry, with vulnerable street workers at the bottom and call girls at the top. This hierarchy dissolves when women's lives are looked at over time. Women also combined jobs within the sex industry with work, education, and training outside. Research participants reported that sex work created the opportunities for such initiatives (qualitative data not shown). However, on completing training, many women stayed in the industry. Given the new possibilities offered by higher education and vocational training, sex work must therefore be considered a positive choice, preferable to alternatives. In other words, sex work is not simply a form of 
social exclusion but a conduit to social mobility and opportunities such as home ownership and a family wage. ${ }^{15}$ Therefore, policies that emphasise "exiting" strategies are likely to have limited impact. Governments may sponsor training schemes for sex workers, but as we have shown women may well train but then combine new skills with sex work in order to retain the economic advantage and flexibility that the occupation can offer. In this study, sex work was a choice for the majority who were followed up, and for many a route out of poverty rather than a vicious circle of social exclusion.

\section{ACKNOWLEDGEMENTS}

We would like to thank all the participants, and to the many collaborators who have contributed to this work over the years. In particular we would like to thank Kate Cooper and Anna Green for data collection in the follow up phase of this study, and the staff of the Praed Street Project and the Jefferiss Wing Clinic.

\section{CONTRIBUTORS}

Both authors contributed to the initial concept and design, data collection and analysis of this study. Both authors drafted, reviewed, and revised the manuscript and have approved the final version.

\section{Authors' affiliations}

H Ward, Department of Infectious Disease Epidemiology, Imperial College London, UK

S Day, Department of Anthropology, Goldsmiths College, University of London, UK

Financial disclosure: Funding for this study was provided by the Wellcome Trust (grant number 053592); earlier data were collected in studies funded by the Medical Research Council, AVERT, North West Thames Regional Health Authority and the Jefferiss Research Trust. The sponsors had no role in the design, collection, analysis or interpretation of the data.

Competing interest: none.

\section{REFERENCES}

1 Visser J, Randers-Pehrson A, Day S, et al. Prostitution policy in the European context, In: Day S, Ward H, eds. Sex work, mobility and health in Europe. London: Kegan Paul, 2004:241-60.

2 Home Office. A coordinated prostitution strategy and a summary of responses to paying the price. London: Home Office, 2005, www.homeoffice.gov.uk/ documents/cons-paying-the-price.

3 Boynton P, Cusick L. Sex workers to pay the price. BMJ 2006;332:190-1.

4 Alary M, Peeters M, Laga M, et al. HIV infection in European female sex workers: epidemiological link with use of petroleum-based lubricants. AIDS 1993; 7:401-8

5 Fennema JSA, Van Ameiiden EJC, Coutinho RA, et al. Clinical sexually transmitted diseases among human immunodeficiency virus-infected and noninfected drugusing prostitutes: associated factors and interpretation of trends, 1986 to 1994. Sex Transm Dis 1997;24:363-71.

6 Philpot CR, Harcourt CL, Edwards JM. A survey of female prostitutes at risk of HIV infection and other sexually transmissible diseases. Genitourin Med $1991 ; 67: 384-8$.

7 Ward H, Day S, Weber JN. Risky business: health and safety in the sex industry over a 9 year period. Sex Transm Infect 1999;75:340-3.

8 Farley M, Barkan H. Prostitution, violence, and post-traumatic stress disorder. Women and Health 1998;27:37-48.

9 Potterat JJ, Brewer DD, Muth SQ, et al. Mortality in a long-term open cohort of prostitute women. Am J Epidemiol 2004;159:778-85.

10 Day S, Ward H, Harris JRW. Prostitute women and public health. BMJ 1988;297:1585.

11 Ward H, Day S, Mezzone J, et al. Prostitution and risk of HIV: female prostitutes in London. BMJ 1993;307:356-8.

12 Day S, Ward H. The Praed Street Project: a cohort of prostitute women in London. In: Plant M, eds. AIDS drugs and prostitution. London: Routledge, 1990.

13 Ward H, Day S, Green A, et al. Declining prevalence of STI in the London sex industry, 1985 to 2002. Sex Transm Infect 2004;80:374-9.

14 Ewing JA. Detecting alcoholism: the CAGE questionnaire. JAMA 1984;252:1905-7.

15 Anon. Prostitution shake-up: one sex worker's view. BMJ 2006;332:245. 